\title{
Nostoc fajok bioaktív metabolitjainak vizsgálata
}

\author{
Riba Milán, Hanyicska Martin, Vasas Gábor
}

Debreceni Egyetem, Növénytani Tanszék, 4032 Debrecen, Egyetem tér 1.

A cianobaktériumok által termelt bioaktív anyagoknak egyre nagyobb tudományos figyelmet szentelnek. A szerkezetileg igen különböző metabolit csoportokhoz sokféle biológiai hatás köthető. Nostoc fajokból korábban már számos antimikrobiális, citotoxikus, tumorellenes enzimgátló, membránstabilitást befolyásoló anyagcsere terméket írtak le. Napjainkban az ismert bioaktív metabolitok száma gyors növekedésnek indult, és farmakológia jelentőségük is egyre nagyobb. Munkánk során az Alföldről származó Nostoc sejtvonalakban 4 peptid típusú bioaktív metabolit csoportot azonosítottunk HPLC-MS/MS módszerrel. A csoportokon belül több, eddig ismeretlen variánst is sikerült teljesen vagy részben azonosítanunk. Nostoginin típusú metabolitok közül 11 új és 1 már ismert variánst határoztunk meg. Ezek a lineáris oligopeptidek aminoproteáz és angiotenzin konvertáló enzim gátló hatásuk miatt elsősorban a kardiovaszkuláris megbetegedések kezelésében játszhatnak fontos szerepet. Sejtvonalainkban 18 anabaenopeptin variánst sikerült részben azonosítanunk. Ezek a ciklikus hexapeptidek protein foszfatázok és proteolitikus enzimek (tripszin, kimotripszin, elasztáz, karboxipeptidáz-A) működését gátolják. Egyetlen izolátum esetében előforduló nostopeptolid A1/A3 egy ciklikus depsipeptid. Ezen csoport több tagja citotoxikus, antifungális valamint peptidáz gátló hatású, illetve egyes variánsok antitoxikusak, gátolják a microcystinek által indukált apoptózist májsejtekben. A leggyakrabban előforduló metabolitok a banyaside-ok, mintáink több mint felében jelentek meg variánsaik. Ezek a glikopeptidek kevésbé ismertek, proteolitikus enzimek múködését gátolják. 13 variáns szerkezetét sikerült részben vagy egészében meghatároznunk.

Témavezető: Vasas Gábor (DE, Növénytani Tanszék) 